\title{
Perilaku Ibu Terhadap Tradisi Perawatan Masa Nifas Di Wilayah Kerja Puskesmas Jeulingke Kota Banda Aceh
}

\section{Mother Behavior Towards Tradition of Postnatal Care in Jeulingke Community Health Centre of Banda Aceh District}

\author{
Faradilla Safitri*1, Nuzulul Rahmi ${ }^{1}$, Karisma Melati ${ }^{1}$, Marniati ${ }^{1}$ \\ ${ }^{1}$ Universitas Ubudiyah Indonesia, Jln. Alue Naga Desa Tibang, Kecamatan Syiah Kuala, Banda Aceh, Indonesia \\ *Correspoding Author : faradilla@uui.ac.id
}

\begin{abstract}
Abstrak
Aceh merupakan salah satu provinsi di Indonesia yang terletak dibagian paling barat gugusan kepulauan nusantara. Dari zaman dahulu masyarakat Aceh sangat konsisten mempertahankan adatistiadat dalam perawatan masa nifas dengan keyakinan bahwa perawatan yang dilakukan berdampak positif dan menguntungkan bagi mereka. Tujuan penelitian ini untuk mengetahui perilaku ibu terhadap perawatan masa nifas di wilayah kerja Puskesmas Jeulingke Kota Banda Aceh. Jenis penelitian bersifat analitik dengan desain cross sectional. Pengumpulan data telah dilaksanakan tanggal 20 November - 12 Desember 2019 di wilayah kerja Puskesmas Jeulingke Kota Banda Aceh. Jumlah populasi sebanyak 30 orang ibu nifas dan pengambilan sampel dengan cara total populasi. Instrumen penelitian menggunakan kuesioner dan pengambilan data dengan cara wawancara. Analisis data meggunakan analisis univariat dan bivariat. Hasil analisis bivariat pengetahuan ( $\mathrm{p}=0.626)$, sikap $(\mathrm{p}=1.000)$, tindakan $(\mathrm{p}=0.000)$. Kesimpulan tidak ada pengaruh pengetahuan dan sikap terhadap tradisi perawatan masa nifas. Diharapkan kepada petugas kesehatan selain memberikan pelayanan kesehatan secara promotif, preventif, kuratif, dan rehabilitative, dapat pula mengkaji dan menyikapi perbedaan tradisi/budaya, isu-isu perawatan masa nifas dan meluruskan keyakinan yang dianut oleh masyarakat yang berhubungan kesehatan.
\end{abstract}

Kata Kunci $\quad$ : Tradisi perawatan masa nifas, pengetahuan, sikap, tindakan

Abstract

Aceh is one of the provinces in Indonesia which is located in the westernmost part of the archipelago. From ancient times the people of Aceh have been very consistent in maintaining the customs in postpartum care with the belief that the treatment carried out has a positive and beneficial impact on them. The purpose of this study was to determine maternal behavior towards postpartum care in the work area of Jeulingke Health Center in Banda Aceh City. This type of research is analytic with cross sectional design. Data collection was carried out on 20 November - 12 December 2019 in the working area of the Jeulingke Health Center in Banda Aceh City. Total population of 30 postpartum mothers and sampling by total population. The research instrument used a questionnaire and data collection by interview. Data analysis uses univariate and bivariate analysis. The results of the bivariate analysis of knowledge $(p=0.626)$, attitudes $(p=1,000)$, actions $(p=0.000)$. Conclusion there is no influence of knowledge and attitudes towards the postpartum care tradition. It is expected that health workers in addition to providing health services in a promotive, preventive, curative and rehabilitative manner, can also examine and respond to differences in traditions / culture, issues of childbirth care and rectify the beliefs held by the health-related community.

Keywords: Tradition of postnatal care, knowledge, attitudes, actions 
Journal of Healthcare Technology and Medicine Vol. 6 No. 1 April 2020

Universitas Ubudiyah Indonesia

e-ISSN : 2615-109X

\section{PENDAHULUAN}

Aceh merupakan salah satu provinsi yang ada di Indonesia dan terletak dibagian paling barat gugusan kepulauan Nusantara. Angka Kematian Ibu menjadi salah satu indikator penting dalam menentukan derajat kesehatan masyarakat khususnya Aceh. Dari data yang bersumber pada dinas kesehatan kabupaten/kota, diketahui jumlah kematian ibu yang dilaporkan sebanyak 141 kasus dan lahir hidup 101.296 jiwa, maka rasio angka kematian ibu di Aceh kembali menunjukkan penurunan menjadi 139 per 100.000 lahir hidup (Dinas Kesehatan Aceh, 2018).

Upaya percepatan penurunan AKI dapat dilakukan dengan menjamin agar setiap ibu mampu mengakses pelayanan kesehatan ibu yang berkualitas, seperti pelayanan kesehatan ibu hamil, pertolongan persalinan oleh tenaga kesehatan terlatihdi fasilitas pelayanan kesehatan, perawatan pasca persalinan bagi ibu dan bayi, perawatan khusus dan rujukan jika terjadi komplikasi, kemudahan mendapatkan cuti hamil dan melahirkan, dan pelayanan keluarga berencana (Kementerian Kesehatan Republik Indonesia, 2016).

Masa nifas merupakan periode kritis dalam keberlangsungan hidup ibu dan bayi baru lahir. Sebagian besa kematian ibu dan bayi baru lahir terjadi dalam 1 bulan pertama setelah persalinan. Untuk itu, perawatan kesehatan selama periode ini sangat dibutuhkan oleh ibu dan bayi baru lahir agar dapat terhindar dari risiko kesakitan dan kematian. World Health Organization (WHO) menganjurkan agar pelayanan kesehatan masa nifas (postnatal care) bagi ibu mulai diberikan dalam kurun waktu 24 jam setelah melahirkan oleh tenaga kesehatan yang kompeten, misalnya dokter, bidan atau perawat (SDKI, 2017).

Perawatan masa nifas merupakan suatu upaya yang dilakukan bidan, ibu nifas dan keluarga dengan tujuan agar kebutuhan nutrisi pada ibu nifas tercukupi, personal hygine terjaga, adanya perawatan payudara, istirahat dan tidur cukup, sehingga dapat mencegah terjadinya tanda bahaya selama masa nifas yang dapat membahayakan kesehatan ibu dan berdampak pada kematian (Nurjanah, 2013).

Kepercayaan dan keyakinan budaya terhadap perawatan ibu post partum, masih banyak di jumpai di lingkungan masyarakat. Mereka meyakini budaya perawatan ibu setelah melahirkan dapat memberikan dampak yang positif dan menguntungkan bagi mereka. Dari hasil penelitian di dapatkan banyak kepercayaan dan keyakinan budaya perawatan ibu post partum, di antaranya pembatasan asupan cairan, makanan di batasi dan hanya boleh makan sayur - sayuran, tidak boleh mandi, diet makanan, tidak boleh keluar rumah, menggunakan alas kaki, menggunakan gurita, tidak boleh tidur di siang hari bahkan mereka meyakini kolustrum tidak baik untuk anak (Mudatsir, 2017). 
Journal of Healthcare Technology and Medicine Vol. 6 No. 1 April 2020

Universitas Ubudiyah Indonesia

e-ISSN : 2615-109X

\section{METODE PENELITIAN}

Penelitian ini menggunakan jenis penelitian yang bersifat analitik dengan desain crosssectional. Populasi dalam penelitian ini adalah seluruh ibu nifas yang berada di wilayah kerja Puskesmas Jeulingke Kecamatan Syiah Kuala Kota Banda Aceh yaitu sebanyak 30 orang, Cara pengambilan sampel dalam penelitian ini adalah total populasi yaitu sebanyak 30 orang. Instrumen penelitian ini menggunakan kuesioner dan pengumpulan data dengan cara wawancara. Pengumpulan telah dilaksanakan pada 20 November 2019 sampai dengan 12 Desember 2019 di Wilayah Kerja Puskesmas Jeulingke Kecamatan Syiah Kuala Kota Banda Aceh. Pengolahan data menggunakan computer melalui proses editing, coding, transferring dan tabulating. Analisis data dengan dua data yaitu analisis univariat dan bivariat.

\section{HASIL PENELITIAN}

Tabel. 1

Distribusi frekuensi karakteristik ibu nifas di wilayah kerja Puskesmas Jeulingke Kota Banda Aceh

\begin{tabular}{clcc}
\hline No & \multicolumn{1}{c}{ Karakteristik } & Frekuensi (f) & Persentase (\%) \\
\hline 1 & Umur & & \\
& a. 20-30 tahun & 14 & 46.7 \\
& b. 31-40 tahun & 16 & 53.3
\end{tabular}

2 Pendidikan
a. Dasar (SD)
23
23
5
6.7
b. Menengah (SMP-SMA sederajat)
c. Tinggi (Perguruan tinggi)
76.7
16.7

3 Pekerjaan
a. Tidak bekerja
26
86.7
b. Bekerja

4 Jumlah Anak
a. 1-2 anak
17
56.7
b. > anak
13
43.3

\section{Total}

30

100.0

Berdasarkan tabel. 1 dapat dilihat bahwa karakteristik ibu nifas di wilayah kerja Puskesmas Jeulingke Kota Banda Aceh adalah ibu dengan rata-rata berumur 31-40 tahun sebanyak 16 orang (53.3\%), pendidikan menengah (SMP-SMA sederajat) sebanyak 23 orang 
Journal of Healthcare Technology and Medicine Vol. 6 No. 1 April 2020

Universitas Ubudiyah Indonesia

e-ISSN : 2615-109X

(76.7\%), tidak bekerja sebanyak 26 orang (86.7\%) dan yang memiliki anak 1-2 orang sebanyak 17 orang $(56.7 \%)$.

Tabel. 2

Distribusi frekuensi perilaku ibu terhadap tradisi perawatan masa nifas di wilayah kerja

Puskesmas Jeulingke Kota Banda Aceh

\begin{tabular}{|c|c|c|c|}
\hline No & Variabel & Frekuensi (f) & Persentase (\%) \\
\hline \multirow[t]{3}{*}{1} & Tradisi perawatan masa nifas & & \\
\hline & a. Tidak pernah & 11 & 36.7 \\
\hline & b. Pernah & 19 & 63.3 \\
\hline \multirow[t]{3}{*}{2} & Pengetahuan & & \\
\hline & a. Rendah & 5 & 16.7 \\
\hline & b. Tinggi & 25 & 83.3 \\
\hline \multirow[t]{3}{*}{3} & Sikap & & \\
\hline & a. Negatif & 12 & 40.0 \\
\hline & b. Positif & 18 & 60.0 \\
\hline \multirow[t]{3}{*}{4} & Tindakan & & \\
\hline & a. Negatif & 11 & 36.7 \\
\hline & b. Positif & 19 & 63.3 \\
\hline & Total & 30 & 100.0 \\
\hline
\end{tabular}

Berdasarkan tabel. 2 dapat dilihat bahwa ibu nifas yang pernah melakukan tradisi perawatan masa nifas sebanyak 19 orang (63.3\%), ibu nifas yang berpengetahuan tinggi terhadap tradisi perawatan masa nifas sebanyak 25 orang $(83.3 \%)$, ibu nifas yang memiliki sifat positif terhadap tradisi perawatan masa nifas sebanyak 18 orang (60.0\%) dan ibu nifas yang mempunyai tindakan positif terhadap perawatan masa nifas sebanyak 19 orang (63.3\%).

Tabel 3

Pengaruh pengetahuan, sikap dan tindakan terhadap tradisi perawatan masa nifas di wilayah kerja Puskesmas Jeulingke Kota Banda Aceh

\begin{tabular}{|c|c|c|c|c|c|c|c|c|}
\hline \multirow[t]{3}{*}{ No } & \multirow[t]{3}{*}{ Variabel } & \multicolumn{4}{|c|}{ Tradisi Perawatan Masa Nifas } & \multicolumn{2}{|c|}{ Jumlah } & \multirow[t]{3}{*}{ P Value } \\
\hline & & \multicolumn{2}{|c|}{ Tidak Pernah } & \multicolumn{2}{|c|}{ Pernah } & & & \\
\hline & & f & $\%$ & $\mathbf{f}$ & $\%$ & $\mathbf{n}$ & $\%$ & \\
\hline 1 & $\begin{array}{l}\text { Pengetahuan } \\
\text { a. Rendah } \\
\text { b. Tinggi }\end{array}$ & $\begin{array}{c}1 \\
10\end{array}$ & $\begin{array}{l}20.0 \\
40.0\end{array}$ & $\begin{array}{c}4 \\
15\end{array}$ & $\begin{array}{l}80.0 \\
60.0\end{array}$ & $\begin{array}{c}5 \\
25\end{array}$ & $\begin{array}{l}100.0 \\
100.0\end{array}$ & 0.626 \\
\hline 2 & $\begin{array}{l}\text { Sikap } \\
\text { a. Negatif } \\
\text { b. Positif }\end{array}$ & $\begin{array}{l}4 \\
7\end{array}$ & $\begin{array}{l}33.3 \\
38.9\end{array}$ & $\begin{array}{c}8 \\
11\end{array}$ & $\begin{array}{l}66.7 \\
61.1\end{array}$ & $\begin{array}{l}12 \\
18\end{array}$ & $\begin{array}{l}100.0 \\
100.0\end{array}$ & 1.000 \\
\hline 3 & Tindakan & & & & & & & \\
\hline
\end{tabular}




$\begin{array}{lccccccc}\text { a. Negatif } & 11 & 100.0 & 0 & 0.0 & 11 & 100.0 & 0.000 \\ \text { b. Positif } & 0 & 0.0 & 19 & 100.0 & 19 & 100.0 & \end{array}$

Berdasarkan tabel. 3 dapat dilihat bahwa dari 5 responden yang berpendidikan rendah dan pernah melakukan perawatan masa nifas sesuai dengan tradisi sebanyak 4 orang (80.0\%), sedangkan dari 25 responden yang berpengetahuan tinggi juga pernah melakukan tradisi perawatan masa nifas sebanyak 15 orang (60.0\%). Hasil uji statistik didapatkan nilai $\mathrm{p}=0.626$, yang artinya tidak ada pengaruh pengetahuan ibu terhadap tradisi perawatan masa nifas di wilayah kerja Puskesmas Jeulingke Kota Banda Aceh.

Pada variabel sikap dapat dilihat bahwa dari 12 responden yang bersifat negatif dan pernah melakukan tradisi perawatan masa nifas sebanyak 8 orang (66.7\%), sedangkan dari 18 responden yang bersifat positif dan pernah melakukan tradisi perawatan masa nifas sebanyak 11 orang $(61.1 \%)$. Hasil uji statistik didapatkan nilai $\mathrm{p}=1.000$, yang artinya tidak ada pengaruh sikap ibu terhadap tradisi perawatan masa nifas di wilayah kerja Puskesmas Jeulingke Kota Banda Aceh

Pada variabel tindakan dapat dilihat bahwa ibu nifas yang memiliki tindakan positif maka pernah melakukan tradisi perawatan selama masa nifas yaitu sebanyak 19 orang (100.0\%), sedangkan ibu nifas yang memiliki tindakan negatif tidak ada yang pernah mengikuti tradisi perawatan masa nifas. Hasil uji statistik didapatkan nilai $\mathrm{p}=0.000$, artinya ada pengaruh tindakan ibu terhadap tradisi perawatan masa nifas di wilayah kerja Puskesmas Jeulingke Kota Banda Aceh.

\section{PEMBAHASAN}

\section{Pengetahuan}

Pengetahuan dapat didefenisikan sebagai fakta atau informasi yang kita anggap benar berdasarkan pemikiran yang melibatkan pengujian empiris (pemikiran tentang fenomena yang diobservasi secara langsung) atau berdasarkan proses berpikir lainnya seperti pemberian alasan logis atau penyelesaian masalah. Pada dasarnya pengetahuan adalah kesadaran dan pemahaman kita terhadap sesuatu dan penerimaan kita sebagai kelompok bahwa pemahaman ini benar (Smiley, 1947). 
Journal of Healthcare Technology and Medicine Vol. 6 No. 1 April 2020

Universitas Ubudiyah Indonesia

e-ISSN : 2615-109X

Pengetahuan tentang perawatan masa nifas yang baik akan membentuk suatu tindakan atau perilaku positif. Seseorang dengan pengetahuan yang cukup dapat menerapkan apa yang ia tahu kedalam pelaksanaan di kehidupan sehari-hari, sehingga perilaku yang baik akan kesehatan khususnya mengenai perawatan pada ibu masa nifas (Yudiyanti.dkk, 2017).

Hasil penelitian ini juga ditemukan masih ada ibu yang tidak mengetahui tentang kebutuhan dasar ibu masa nifas yang seharusnya terpenuhi seperti kebutuhan karbohidrat, protein, vitamin dan mineral, dan masih adanya anggapan bahwa mengkonsumsi makanan tertentu dapat berdampak negatif, misalnya minum air putih hanya 5 gelas per hari, dan mengkonsumsi buah jeruk, pisang dan papaya dapat membuat bayi diare, pendapat tersebut tidak tepat, selama masa nifas ibu membutuhkan vitamin dan mineral agar tubuh ibu tetap sehat, serta dapat menghindari dari sembelit.

Sama halnya dengan teori yang disampaikan oleh Walyani dan Purwoastuti (2017), buah-buahan sangat baik untuk menjaga kebugaran tubuh dan sana sekali tidak berpengaruh buruk terhadap mutu ASI. Ibu nifas membutuhkan asupan makanan berserat seperti buah dan sayur mayur untuk memperlancar buang air besar dan konsumsi buah membantu proses pencernaan, kadar vitamin dan air dalam buah juga sangat baik untuk menjaga kesehatan tubuh.

\section{Sikap}

Sikap adalah respon tertutup seseorang terhadap stimulus atau objek tertentu, yang sudah melibatkan faktor pendapat dan emosi yang bersangkutan. Sikap melibatkan pikiran, perasaan, perhatian, dan gejala kejiwaan yang lain (Notoatmodjo, 2012).

Hasil penelitian yang dilakukan oleh Eldawati di Kecamatan Gunung Pati Kota Semarang tentang hubungan pengetahuan dan sikap ibu nifas dengan perawatan masa nifas diperoleh adanya lebih dari setengah responden yang sudah memiliki sikap yang baik tentang perawatan masa nifas hal ini disebabkan oleh adanya lebih dari setengah dari responden yang sudah tidak mempercayai akan budaya dimasyarakat mengenai perawatan masa nifas yang tentukan hal ini akan memberi dampak yang positif terhadap kesehatan ibu selama masa nifas (Eldawati, 2015). 
Journal of Healthcare Technology and Medicine Vol. 6 No. 1 April 2020

Universitas Ubudiyah Indonesia

e-ISSN : 2615-109X

\section{Tindakan}

Menurut Notoatmodjo (2012), suatu sikap belum otomatis terwujud dalam suatu tindakan (over behavior). Untuk mewujudkan sikap menjadi suatu perbuatan diperlukan faktor pendukung atau suatu kondisi yang memungkinkan.

Tradisi perawatan masa nifas yang dilihat pada penelitian ini bukan hanya yang bersifat negatif saja salah satunya seperti adanya pantangan makanan, namun juga dalam tradisi yang positif misalnya seperti meminum jamu dan membubuhi ramuan-ramuan dari bahan tradisional pada tubuh ibu selama masa nifas.

Hasil penelitian memperlihatkan bahwa kepercayaan ibu nifas terhadap budaya dan tradisi perawatan masa nifas masih ada, walaupun tidak semua ibu nifas mengikuti tradisi tersebut. Adapun beberapa tradisi/budaya yang biasanya dilakukan oleh ibu nifas adalah salah satunya meminum jamu khusus bersalin, ada sebanyak 18 orang (60.0\%) ibu yang mengkonsumsi jamu setiap pagi selama masa nifas, hal ini dipercayai dapat membuat tubuh menjadi lebih sehat dan juga jamu dipercayai mempercepat proses penyembuhan selama masa nifas serta mengeluarkan darah kotor dari dalam rahim.

Tradisi/kebiasaan lainnya dalam perawatan ibu nifas adalah mengoleskan param keseluruh tubuh sebanyak 22 orang (73.3\%), dengan anggapan bahwa membuat tubuh menjadi lebih hangat dan segar, dan meletakkan pilis di dahi sebanyak 21 orang $(70.0 \%)$ dengan anggapan dapat mencegah penglihatan kabur.

Perawatan nifas dengan melakukan urut atau pijat, memakai pilis, parem dan tapel adalah merupakan perawatan yang dapat memberikan manfaat kesehatan bagi ibu nifas terhadap budaya perilaku hidup sehat. Sejak hari pertama sampai dengan hari ketiga seluruh tubuh ibu di urut, dalam upaya membersihkan darah kotor dan melancarkan ASI. Selama dalam perawatan nifas ibu juga diolesi tapel, pilis, dan parem. Hal ini bertujuan untuk menghaluskan muka, tubuh dan mengencangkan kulit. Perencanaan dan implementasi dari Teori ini sangat relevan dan diterapkan secara nyata dalam praktek keperawatan, karena teori ini sesuai dengan budaya perilaku hidup sehat (Mudatsir, 2017).

Selanjutnya tradisi perawatan masa nifas di Aceh adalah tindakan berbaring diatas tikar yang terbuat dari bambu yang dibawahnya diletakkan arang panas atau yang biasa disebut sale, ada sebanyak 2 orang (6.6\%) yang pernah melakukan perawatan seperti ini, dengan kepercayaan dapat mengurangi lemak pada tubuh dan membuat tubuh menjadi lebih bugar. Tindakan bakar batu (toet bate) yang diletakkan diatas perut ibu ada sebanyak 6 orang 
Journal of Healthcare Technology and Medicine Vol. 6 No. 1 April 2020

Universitas Ubudiyah Indonesia

e-ISSN : 2615-109X

(20.0\%) ibu yang pernah melakukan tradisi ini, dengan anggapan dapat mempercepat proses pengecilan rahim dan dapat mengeluarkan darah kotor.

Proses madeung dilaksanakan selama empat puluh empat hari, dimulai pada hari kedua pasca melahirkan. Teknis pelaksanaan madeung dan sale ini dimulai dengan memanaskan batu, selanjutnya batu diangkat dan dibalut dengan menggunakan kain atau daun jarak pagar. Kemudian batu tersebut disandarkan pada bagian perut wanita bersalin yang sedang dalam posisi tidur diatas balai yangtelah disediakan. Proses madeung dan sale mempercepat proses penyembuhan ibu pasca melahirkan, mengembalikan stamina, dapat menurunkan berat badan, mengeluarkan keringat dalam jumlah banyak sehingga meningkatkan kapasitas detoksifikasi kulit dengan mengeluarkan kotoran dari badan, serta menjadikan ibu awet muda (Fuadi, 2018).

Tradisi perawatan yang biasanya dilakukan oleh ibu nifas pada penelitian ini lainnya adalah melakukan kusuk (urut) yaitu sebanyak 24 orang (80.0\%) dengan anggapan membuat tubuh menjadi lebih bugar, ibu nifas yang menggunakan kaos kaki sebanyak 21 orang (70.0\%) dengan anggapan agar tidak kedinginan, tidak keluar rumah selama 40 hari sebanyak 18 orang $(60.0 \%)$, tidak memasak selama masa nifas sebanyak 11 orang $(36.6 \%)$, menggunakan kroset/gurita sebanyak 25 orang (83.3\%), dan 6 orang (20.0\%) yang pernah melakukan prosesi mandi hari ke-44 setelah melahirkan menggunakan buah jeruk perut dan berbagai jenis bunga lainnya.

Berdasarkan hasil penelitian Sri, Mudatsir dan Hasballah yang dilakukan di Kecamatan Tanah Jambo Aye Kabupaten Aceh Utara, perawatan yang diberikan paska melahirkan di antaranya masih ada yang menggunakan budaya pada masa nifasnya. Masyarakat masih mempercayai adanya beberapa pantangan makanan bagi ibu nifas, setelah melahirkan ibu dimandikan dengan ie boh kruet (jeruk perut), diberikan ramuan daun-daunan, diletakkan batu panas di perut dipeumadeung (disale), seluruh tubuh ibu di urut, di bagian muka dan badan ibu di beri bedak dingin dan obat- obatan ramuan, ibu tidak boleh keluar rumah selama 40 hari dan masih banyak perawatan lainnya yang diberikan setelah melahirkan. Hal tersebut dilatarbelakangi oleh nilai, adat istiadat, kepercayaan dan sikap dari masyarakat yang menjadi faktor budaya dalam perawatan ibu nifas (Mudatsir, 2017)

Selain tradisi/kebiasaan perawatan masa nifas tersebut, ada beberapa kebiasaan negatif yang dilakukan pada ibu selama masa nifas, seperti pantang makan ikan sebanyak 
Journal of Healthcare Technology and Medicine Vol. 6 No. 1 April 2020

Universitas Ubudiyah Indonesia

e-ISSN : 2615-109X

24 orang $(80.0 \%)$, tidak makan telur sebanyak 25 orang $(83.3 \%)$, tidak makan daging sebanyak 22 orang (73.3\%) dan minum sedikit air putih sebanyak 23 orang (76.6\%).

Masa nifas merupakan masa setelah melahirkan sampai dengan pulihnya kembali alatalat kandungan seperti sebelum hamil. Masa nifas ini menjadi masa yang paling rentan bagi ibu dikarenakan penyumbang kematian ibu yang paling besar dalam masa nifas. Dengan demikian, pada masa ini dibutuhkan pengawasan dan perawatan yang tepat dan cepat agar angka kesakitan dan kematian dapat dikurangi. Perawatan nifas merupakan perawatan lebih lanjut bagi wanita sesudah melahirkan. Perawatan masa nifas yang tepat menjadi salah satu upaya untuk dapat membantu dan mempercepat proses kembali pulihnya alat-alat reproduksi, kebutuhan nutrisi, pencegahan infeksi serta dapat memulihkan kesehatan emosi ibu.

Masyarakat Aceh memiliki kepercayaan yang cukup kental dalam merawat ibu nifas, tradisi ini telah dilakukan sejak lama dan turun temurun sampai dengan sekarang, ada beberapa tradisi perawatan pada ibu masa nifas yang memang apabila dilihat dari segi kesehatan juga bermanfaat seperti jamu dan ramuan-ramuan lainnya yang dipercayai dapat membuat tubuh menjadi lebih sehat, namun hal ini masih perlu penelitian lebih lanjut. Adapula tradisi/budaya yang berdampak buruk bagi kesehatan misalnya seperti adanya kepercayaan pantangan mengkonsumsi beberapa jenis makanan.

Pada era global seperti sekarang ini, memang ada beberapa tradisi yang hilang atau tidak dilakukan lagi oleh masyarakat Aceh khususnya yang berada di kawasan perkotaan, dikarenakan kepercayaan ibu-ibu muda memiliki perbedaan pendapat dengan orang tuanya, hal ini dapat dipengaruhi oleh pengetahuan, pendidikan, dan pekerjaan ataupun aktifitas yang biasa ditekuni oleh ibu muda, sehingga apabila ada beberapa budaya yang sedikit membebani, atau membuat ibu tidak nyaman, maka hal itu tidak dilakukan.

Petugas kesehatan memiliki peran yang sangat penting dalam hal perawatan ibu masa nifas, selain untuk memantau proses pemulihan kembali alat-alat reproduksi, memberikan ibu dan keluarga pemahaman tentang kebutuhan selama masa nifas, baik itu perawatan ibu maupun bayinya, pencegahan ibu dari infeksi masa nifas dan juga petugas kesehatan dapat mengkaji pendekatan tradisi/budaya yang dilakukan masyarakat, tenaga kesehatan juga harus mampu menyikapi perbedaan budaya serta isu-isu budaya yang dapat berpengaruh terhadap kesehatan.

\section{SIMPULAN}


Journal of Healthcare Technology and Medicine Vol. 6 No. 1 April 2020

Universitas Ubudiyah Indonesia

e-ISSN : 2615-109X

Berdasarkan hasil penelitian dapat disimpulkan bahwa tidak ada pengaruh pengetahuan $(\mathrm{p}=0.626)$ dan sikap $(\mathrm{p}=1.000)$ terhadap tradisi perawatan masa nifas di Wilayah Kerja Puskesmas Jeulingke Kota Banda Aceh dan tindakan berpengaruh terhadap tradisi perawatan masa nifas di Wilayah Kerja Puskesmas Jeulingke Kota Banda Aceh, dengan nilai p =0.000.

\section{SARAN}

Diharapkan kepada petugas kesehatan selain memberikan pelayanan kesehatan secara promotif, preventif, kuratif, dan rehabilitative, dapat pula mengkaji dan menyikapi perbedaan tradisi/budaya, isu-isu perawatan masa nifas dan meluruskan keyakinan yang dianut oleh masyarakat yang berhubungan kesehatan.

\section{UCAPAN TERIMA KASIH}

Ucapan terima kasih kepada Universitas Ubudiyah Indonesia yang telah memberikan dukungan finansial dalam penelitian ini dan ucapan terima kasih kepada Kepala Puskesmas Jeulingke yang telah memberikan izin penelitian diwilayah kerjanya dan para responden yang telah membantu peneliti dalam memberikan informasi yang dibutuhkan peneliti.

\section{DAFTAR PUSTAKA}

Dinas Kesehatan Aceh. (2018). Profil Kesehatan Aceh. Banda Aceh.

Eldawati, S. (2015). Hubungan Pengetahuan Dan Sikap Ibu Nifas Dengan Praktik Perawatan Masa Nifas Di Kecamatan Gunungpati Kota Semarang Bulan Januari-Maret 2015. Jurnal Kesehatan Masyarakat (e-Journal), 3(3), 228-237.

Fuadi, T. M. (2018). Prosiding Seminar Nasional Biotik 2018 PENGOBATAN TRADISIONAL MADEUNG DAN SALE PADA IBU MASA NIFAS DALAM MASYARAKAT ACEH.

Kementerian Kesehatan Republik Indonesia. (2016). Profil Kesehatan Indonesia 2016. In Profil Kesehatan Provinsi Bali. Retrieved from http://www.depkes.go.id/resources/download/pusdatin/profil-kesehatanindonesia/Profil-Kesehatan-Indonesia-2016.pdf

Mudatsir, M. (2017). Faktor Budaya Dalam Perawatan Ibu Nifas. Jurnal Ilmu Keperawatan, $5(1), 36-49$.

Notoatmodjo, S. (2012). Promosi Kesehatan dan Perilaku Kesehatan. Jakarta: PT Rineka Cipta.

Nurjanah, M. dan B. (2013). Asuhan Kebidanan Postpartum dilengkapi dengan Asuhan Kebidanan Post Sectio Caesarea (Pertama). Bandung: Refika Aditama.

SDKI. (2017). Strategi Pelaksanaan Program Keluarga Berencana Berbasis Hak untuk Percepatan Akses terhadap Pelayanan Keluarga Berencana dan Kesehatan Reproduksi yang Terintegrasi dalam Mencapai Tujuan Pembangunan Indonesia. 100.

Smiley, W. L. (1947). Early postpartum ambulation. Missouri Medicine, 44(10), 756-758.

Walyani dan Purwoastuti. (2017). Asuhan Kebidanan Masa Nifas dan Menyusui. Yogyakarta. Yudiyanti.dkk. (2017). PENGETAHUAN IBU TENTANG MATERI PERAWATAN MASA 
Journal of Healthcare Technology and Medicine Vol. 6 No. 1 April 2020

Universitas Ubudiyah Indonesia

e-ISSN : 2615-109X

NIFAS DALAM BUKU KIA DENGAN KETERATURAN KUNJUNGAN NIFAS Ika Yudianti, Ari Kusmiwiyati, Puji Rahayu. 71-78. 